MaPan : Jurnal Matematika dan Pembelajaran

p-ISSN: 2354-6883 ; e-ISSN: 2581-172X

Volume 8, No 1, June 2020 (1-18)

DOI: https://doi.org/10.24252/mapan.2020v8n1a1

\title{
IDENTIFYING STUDENTS' DIFFICULTIES IN UNDERSTANDING AND APPLYING PYTHAGOREAN THEOREM WITH AN ONTO-SEMIOTIC APPROACH
}

\author{
Rudi $^{1)}$, Didi Suryadi2), Rizky Rosjanuardi ${ }^{3}$ ) \\ 1,2,3Program Pasca Sarjana Pendidikan Matematika Universitas Pendidikan Indonesia \\ ${ }^{1}$ LPMP Sulawesi Selatan Indonesia \\ 1,2,3Jl. Dr. Setiabudhi, Bandung, Indonesia; 1 Jl. A. P. Pettarani, Makassar, Indonesia \\ E-mail: rudi.math@upi.edu ${ }^{1)}$, didisuryadi1@gmail.com²), rizky@upi.edu3)
}

Received April 29, 2020; Revised May 11, 2020; Accepted June 09, 2020

\begin{abstract}
:
This research is conducted to obtain a description of students' difficulties in understanding and applying Pythagorean theorem based on the onto-semiotic approach. This research applies a qualitative approach with phenomenology interpretation design. Research data were collected using test and interview methods. The research result was deducted from students' answer sheets and interviews. Participants involved in this study were as many as 25 students of UPI Lab School Junior High School Bandung, who had learned Pythagorean theorem, 4 of which also participated in the interview. It showed that students found it complicated to comprehend definition, describe symbols or notations of mathematical objects, and interpret mathematical objects. Meanwhile, in solving problems related to the application of the Pythagorean theorem, students could describe procedure, algorithm, and technique in solving questions well.
\end{abstract}

Keywords: Student Difficulties, Onto-Semiotic Approach, Pythagorean Theorem

\section{IDENTIFIKASI KESULITAN SISWA DALAM MEMAHAMI DAN MENERAPKAN TEOREMA PYTHAGORAS DENGAN PENDEKATAN ONTO-SEMIOTIKA}

\begin{abstract}
Abstrak:
Penelitian ini bertujuan untuk mendapatkan gambaran kesulitan siswa dalam memahami dan menerapkan Teorema Pythagoras menggunakan pendekatan ontosemiotika. Penelitian ini menggunakan pendekatan kualitatif dengan desain interpretasi fenomenologi. Metode pengumpulan data, yaitu tes dan wawancara. Partisipan penelitian yang dilibatkan dalam uji kemampuan siswa adalah 25 orang siswa SMP Lab School UPI Bandung yang pernah belajar materi teorema Pythagoras, 4 orang dari 25 orang siswa tersebut dilibatkan dalam wawancara. Hasil penelitian menunjukkan bahwa siswa mengalami kesulitan dalam memahami definisi, mendeskripsikan simbol atau notasi dari objek matematika, serta kesulitan dalam memaknai objek matematika, sedangkan dalam menyelesaikan permasalahan penerapan teorema Pythagoras, siswa mampu mendeskripsikan prosedur, algoritma, dan teknik penyelesaikan masalah dengan baik.
\end{abstract}

Kata kunci: Kesulitan Siswa, Pendekatan Onto-Semiotika, Teorema Pythagoras

Copyright () 2020, MaPan: Jurnal Matematika dan Pembelajaran 
How to Cite: Rudi, Suryadi, D., \& Rosjanuardi, R. (2020). Identifying Students' Difficulties in Understanding and Applying Pythagorean Theorem with an OntoSemiotic Approach. MaPan: Jurnal Matematika dan Pembelajaran, 8(1), 1-18. https://doi.org/10.24252/mapan.2020v8n1a1.

\section{INTRODUCTION}

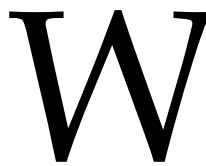

ithin the process of achieving learning objectives, students face several issues. Two of those issues in the mathematics learning context are student errors and misunderstanding. Student error and misunderstanding usually happen due to student difficulties. Teachers' knowledge of student learning errors, misunderstandings, and difficulties plays a crucial role in this case. Teachers who are knowledgeable of the cause of student misunderstanding can take preventive action to create a more efficient learning environment (Ojose, 2015). Locating and overcoming student misunderstanding will help teachers to understand students' backgrounds and perceptions on academic subjects and form their teaching methods (Murphy, Alexander, Greene, \& Hennessey, 2004). Analysis of student learning obstacles will increase teachers' belief and knowledge about students (Sbaragli, Arrigo, D'Amore, Fandino-Pinilla, Frapolli, Frigerio, \& Villa, 2011). Teachers' experience in dealing with student errors, misunderstandings, and difficulties will likely improve teachers' competence and knowledge.

Mathematical objects are a significant aspect of learning mathematics (Iori, 2017). Mathematical objects are anything used when communicating or learning about mathematics. The theoretical idea regarding the use of ontosemiotic in mathematics education was firstly introduced by (Font, Godino, \& D' Amore, 2007). This idea about the use of interdisciplinary in mathematics education. The onto-semiotic approach is a theoretical framework combining mathematical cognition and teaching with other disciplines like semiotics, anthropology, and ecology (Font, Godino, \& D' Amore, 2007).

Pythagorean theorem is one of the most well-known geometry theorems in the world. This theorem is almost always found in all reference books of mathematics, science, and science history (Font, Godino, \& D' Amore, 2007). In book publication, the Pythagorean theorem always becomes a subject of interest. As a part of geometry and measurement topics, it serves as a topic within the curriculum in each country (Maor, 2019). The topic of the Pythagorean theorem is found and applied in every education level. This makes 
Pythagorean theorem become the most memorized topic for everyone who has ever participated in formal education.

In achieving the basic competence of the Pythagorean theorem, some learning difficulties were spotted to happen to students. Research conducted by Hutapea, Suryadi, \& Nurlaelah (2015) revealed that students tended to apply the instant way of solving mathematical questions without understanding the concept, memorize complete formulas without a thorough understanding of Pythagorean theorem concept, and fail to answer questions with visual and implicit information. Interview results showed that students did not like questions in the form of a story, which included long details.

In 2017, Anggraini \& Ariyanto completed research on students in a Junior High School in Central Java. Anggraini \& Ariyanto (2017) figured out that students found complexities in understanding and applying the Pythagorean theorem. Those difficulties appeared when students dealt with algebra operation, determined hypotenuse, and expressed ideas related to the Pythagorean theorem. Meanwhile, a study by Robbia (2013) mentioned that students went through complexities in applying Pythagorean theorem in mathematical problems which needed initial construction. Another learning obstacle discovered by Robbia (2013) was student difficulty in solving problems which involved variable.

The onto-semiotic approach is an approach in understanding the meaning or nature (ontology) of mathematical objects covering three mathematical aspects namely problem-solving activity, symbolic language, and organized logical and conceptual system (Godino, Batanero, \& Roa, 2005; Montiel, Wilhelmi, Vidakovic, \& Elstak 2009). Onto-semiotic approach (Godino, Batanero, \& Font, 2007; Font, Godino, \& D' Amore, 2007) consists of 6 main components covering language (term, expression, notation, and graphic), situation, (problem, extra application or intra-mathematics, practice, etc.), definition or description of mathematical ideas (number, dot, straight line, mean, equation, etc.), proposition, property, or attribute which is usually in the form of the statement, procedure, or subject action in solving mathematical problems (operation, algorithm, technique, procedure), and arguments used to validate and explain or against proposition (confirming or refuting). This research only focused on two components, namely definition or description of mathematical ideas, and statement, procedure, or subject action in solving mathematical problems. 
Several studies have applied an onto-semiotic approach to analyze mathematics learning. Montiel, Wilhelmi, Vidakovic, \& Elstak (2009) applied an onto-semiotic approach in analyzing students' mathematical concepts on the topic of the coordinate system. The use of the onto-semiotic approach was then executed by Amin, Juniati, \& Sulaiman (2018) in analyzing junior high school students' competence on the topic of algebra.

Student difficulties can be used to increase teacher knowledge (Brodie, 2014). Likewise, vice versa, teacher knowledge plays a role in overcoming student difficulties (Zuya \& Kwalat, 2015). Several facts show that teachers have difficulty in identifying and overcoming student difficulties (Celik, \& Guzel, 2017; Al-Khateeb, 2016; Zuya, 2014). One reason is that the approach used in analyzing student difficulties is incompatible with the approach used to analyze teacher knowledge. The onto-semiotic approach is the theoretical basis of the Didactic Mathematical Knowledge (DMK) (Pino-Fan, Assis, \& Castro, 2015). DMK is a theoretical framework for analyzing teacher knowledge (Pino-Fan, Godino, \& Font, 2018). The use of the onto-semiotic approach in analyzing student difficulties will facilitate the study and analysis of teacher knowledge because the onto-semiotic approach can also be used to analyze teacher knowledge.

Despite the fact above, a study that employs the onto-semiotic approach in analyzing student learning difficulties, especially within the topic of the Pythagorean theorem, has not yet existed. The existing research investigating student difficulties has not yet applied onto-semiotic as the analysis tool. Based on facts, this study aims to investigate the use of the onto-semiotic approach in student learning difficulty analysis within the topic of the Pythagorean theorem.

\section{RESEARCH METHOD}

The phenomenon being subject to investigation in this study is student difficulties in understanding and applying the Pythagorean theorem. Two types of activities were performed to reveal meanings or facts related to the phenomenon of student difficulties. The first one is testing students' competence through written test. The second one is a structured interview to explore students' answers on the written test more deeply. A list of questions and descriptions of the results of this study were developed based on the ontosemiotic approach. Therefore, this study applies a qualitative approach with phenomenology interpretative design. 
Typical case sampling and expert sampling (Etikan, Musa, \& Alkassim, 2016) are some of the reasons the research participants are selected purposively and are based on planning (Cresswell, 2014). UPI Lab School Junior High School Bandung is a school specially prepared by UPI as a place for student research. UPI Bandung Lab School students are accustomed to interacting with research students.

The number of participants in this research was 25 students of grade IX. This was the number of students in one class in a junior high school in Bandung. Out of those 25 students, 4 students identified to face difficulties in answering mathematics questions were chosen. The participants taking part in an interview session in this research are later called participants A, B, C, and D. The researchers then conducted a structured interview to explore students' complexities in solving geometry problems.

In this research, data were collected through students' competence written test and interview. Students' competence tests are given to one class of 25 students. The students' competence test results are then analyzed and grouped according to the type of error. Furthermore, the results of the grouping are used to determining 4 research subjects. Then an interview was conducted to identify the difficulties that caused the students' errors.

Test on students' competence was carried out using an instrument arranged based on indicators of students' competence within the topic of the Pythagorean theorem. Besides, researchers prepared a list of questions to explore students' answers. A list of questions was formed based on the ontosemiotic approach. The instrument to test students' competence consisted of 4 questions; 2 questions regarding the understanding of Pythagorean theorem concept and 2 questions regarding the application of Pythagorean theorem.

Competence of understanding Pythagorean theorem consists of two indicators; namely, students can determine the length of a side of a right triangle (first question), and students can determine whether a series of numbers belongs to Pythagorean triple numbers (second question). The competence of applying the Pythagorean theorem consists of two indicators as well covering students can apply the Pythagorean theorem to determine a side of the trapezium (third question). Furthermore, students can apply the Pythagorean theorem to determine the diagonal side of a rectangle if the rectangle area and one of its sides have been previously known (fourth question).

The techniques applied were data collection, data reduction, data presentation, and data conclusion (Miles, Huberman, \& Saldana, 2018). The data 
analysis steps on student learning difficulties carried out by the researchers were described as follows. After students responded to the given questions, their answers were checked and later categorized according to the types of mistakes they made.

The interview was then performed to explore student difficulties. The onto-semiotic approach used to analyze student difficulties was based on the process of interpreting mathematical objects (Font, Godino, \& D' Amore, 2007). Therefore, the interview served as an effort to reveal the process of students' understanding of mathematical objects.

\section{RESULTS AND DISCUSSION}

This study elaborates on student difficulties based on two main indicators of students' competence achievement on the Pythagorean theorem topic. The two main indicators understood of Pythagorean theorem concept and application of Pythagorean theorem. In this section, research findings are presented in the form of recapitulation on students' competence, answers, and interview transcript.

\section{Student Difficulties in Understanding the Concept of Pythagorean Theorem}

Like what has been done on proving Pythagorean theorem competence, this research applied two questions stated on the first and second questions to figure out students' competence in understanding the concept of the Pythagorean theorem. The first and second questions were stated as follows.

\section{First Question:}

Find the unknown length of the side of the right triangle:

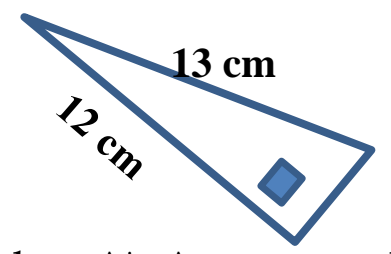

Figure 1. Student A's Answer on the First Question

\section{Second Question:}

Prove whether or not the following number series belong to triple Pythagorean numbers: 12, 15, 8 . 
Table 1. Students' Ability to Solve the First Question

\begin{tabular}{cccc}
\hline Question 1 & $\begin{array}{c}\text { Correct } \\
\text { Answer }\end{array}$ & $\begin{array}{c}\text { Incorrect } \\
\text { Answer }\end{array}$ & No Answer \\
\hline Total Students & 17 & 8 & 0 \\
$\%$ & 68 & 32 & 0 \\
\hline
\end{tabular}

Table 2. Students' Ability to Solve the Second Question

\begin{tabular}{cccc}
\hline Question 2 & $\begin{array}{c}\text { Correct } \\
\text { Answer }\end{array}$ & $\begin{array}{c}\text { Incorrect } \\
\text { Answer }\end{array}$ & No Answer \\
\hline Total Students & 5 & 16 & 4 \\
$\%$ & 20 & 64 & 16 \\
\hline
\end{tabular}

Table 1 and table 2 shows that those students are more difficult in determining whether a pair of numbers is a Pythagorean triple than to determine the length of one side of a right triangle.

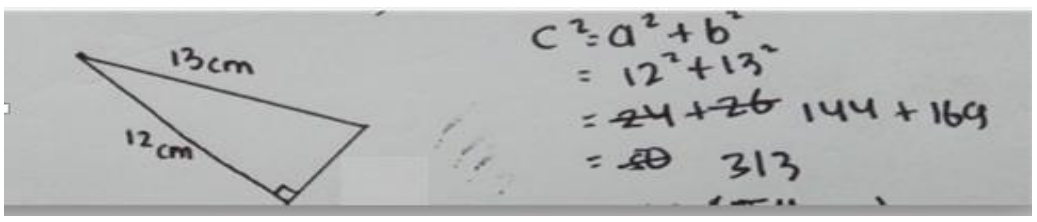

Figure 2. Student A's Answer on the First Question

Below is the interview transcript between a researcher and student $\mathrm{A}$ regarding his answer to the first question.

Researcher : What do you think about the first question? Is it hard or not?

A : I guess in between, Sir.

Researcher : Why do you think this question is easy?

A : It is because I have already memorized the Pythagorean formula, Sir.

Researcher : Can you please explain your answer?

A : I memorize Pythagorean formula like this, Sir (while pointing out at the equation of $a^{2}+b^{2}=c^{2}$ ).

Researcher : Do you memorize that?

A : I memorize the formula by rote.

Researcher : Next, where do you get $12^{2}+13^{2}$ ?

A : Well, Sir, I just apply for the numbers in the questions into the formula. The numbers in the 
picture are 12 and $b$ 13. Next, I add them, and I get 313.

Researcher : Do you know what are represented by symbols $a, b$, and $\mathrm{c}$ in Pythagorean formula?

A : No, Sir. I just memorize the formula.

Researcher : Are you aware of the hypotenuse, adjacent, and opposite?

A : I have ever heard about it, Sir. However, I do not know where their positions are.

Researcher : Do you know about the right triangle?

A : I do, Sir. It is a triangle of which one of the angles is 90 degrees. It is usually marked by a sign like this (while pointing at a right triangle in the question).

Researcher : When learning about the Pythagorean theorem, do you learn the characteristics of the right triangle?

A : : Only when doing a practice like this, the teacher told me that there were hypotenuse, adjacent, and opposite sides in a triangle. However, the picture in this question is different from the picture that we had in practice. So, I was confused in the beginning.

Interview results with student A showed that the student remembered and memorized the equation or formula of the Pythagorean theorem. The student did not interpret symbols or notations a, b, and c as symbols of adjacent, opposite, and hypotenuse. It caused students to face difficulties in determining and look for the unknown side of a right triangle. Based on onto-semiotic, this phenomenon signified that students found it complicated to understand the definition or describe symbols or notations of mathematical objects in the form of numbers, dots, lines, means, and functions (Godino, Batanero, \& Roa, 2005; Font, Godino, \& D' Amore, 2007).

Based on the interview with student A regarding the process of solving the first question, it was figured out that he experienced difficulties in determining hypotenuse, adjacent, and the opposite of a right triangle, and student experienced difficulties in solving the first question because of the changing context of the question. Students had difficulty in determining the length of one between the sides of a right triangle by using the Pythagorean theorem (Alfian, Sugiatno, \& Hamdani, 2016). 
It meant that the student did not understand the concept of a right triangle. Understanding the concept of a triangle is the main prerequisite to be able to solve the first question. Lesson on the topic of the right triangle had been learned by student A previously in grade VIII. Mathematics learning is cumulative prose (Ham \& Heinze, 2018), which means that to learn a new topic, students need to master previously learned topics. The process which does not undergo assimilation and accommodation steps will cause student errors and misunderstandings (Sarwadi \& Shahrill, 2014). Many sources of students' difficulties have connections with students' prior knowledge (Qian \& Lehman, 2017).

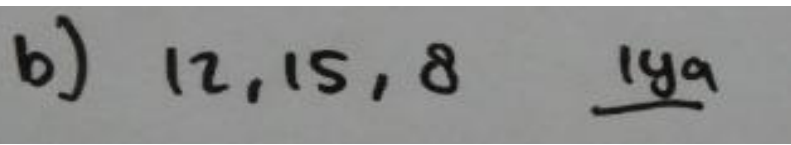

Figure 3. Student B's Answer on the Second Question

The interview transcript regarding student B's answer on the second question is presented below.

Researcher : What do you think about question number 2? Is it hard or not?

B : I think it is in between.

Researcher : Can you explain your answer? Why do you answer 'yes'? How is the process that you go through until you say yes?

B : When learning about the Pythagorean theorem, the teacher taught me the instant way to solve the Pythagorean theorem question, but I need to memorize the series of triple Pythagorean numbers.

The result of the interview with student $B$ revealed that the student understood what was asked in the questions. This signified that he had a good understanding of mathematical objects in the form of symbols or notations in a question. However, the result of the next interview revealed that students faced difficulties in solving the given problems. This was due to student misunderstanding on the instant way taught by the teacher. Based on the ontosemiotic approach, this phenomenon showed that students found it difficult to interpret mathematical objects within the procedure of mathematics problem solving (Godino, Batanero, \& Roa, 2005; Font, Godino, \& D' Amore, 2007). 
Based on the answer sheet and interview with student B in solving the second question, it was revealed that the student found it complicated in determining whether or not a number series belonged to triple Pythagorean. This was due to the student's use of instant technique or procedure taught by the teacher. Other than this case, students faced complexities in solving problems, and they only applied the rote learning approach. It caused students to deny the calculation outcome that they got. The Rote learning method is ineffective to be applied (Ishartono, Nurcahyo, \& Setyono, 2019) and the main cause of learning difficulties in mathematics, especially in geometry (Ahmady \& Ruhi, 2016).

\section{Student difficulties in applying the Pythagorean theorem}

Like the previous two competencies, this section applied two questions to measure students' ability in Pythagorean theorem application. The two questions are as follows.

\section{Third question:}

There is a two-dimensional figure of the trapezium in the following picture.

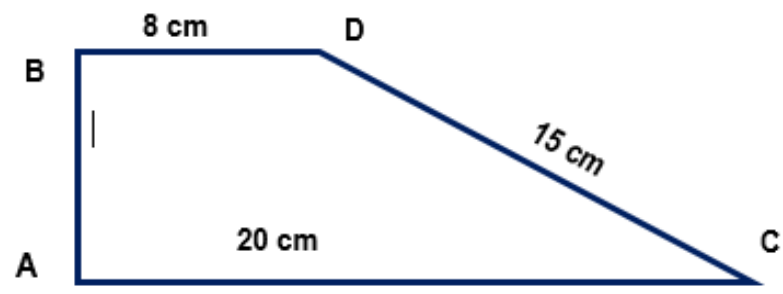

Figure 4. Student B's Answer on the Second Question

Referring to the Pythagorean theorem, determine the length of the side AB!

\section{Fourth question:}

A farmer named Mr. Sabar has a patch rectangle rice field with an area of $120 \mathrm{~m}^{2}$ and a length of $15 \mathrm{~m}$. Referring to the Pythagorean theorem, calculate the length of Mr. Sabar's rice field diagonal?

Table 3. Students' Ability to Solve the Third Question

\begin{tabular}{ccc}
\hline Question 3 & Correct Answer & Incorrect Answer \\
\hline Total students & 11 & 11 \\
$\%$ & 44 & 44 \\
\hline
\end{tabular}


Table 4. Students' Ability to Solve the Fourth Question

\begin{tabular}{cccc}
\hline Question 4 & $\begin{array}{c}\text { Correct } \\
\text { Answer }\end{array}$ & $\begin{array}{c}\text { Incorrect } \\
\text { Answer }\end{array}$ & No Answer \\
\hline Total students & 6 & 10 & 9 \\
$\%$ & 24 & 40 & 36 \\
\hline
\end{tabular}

Table 3 and table 4 shows that students find it more difficult to apply the Pythagorean theorem to determine the circumference of a flat figure than to apply the Pythagorean theorem to determine the diagonal length of a flat figure.

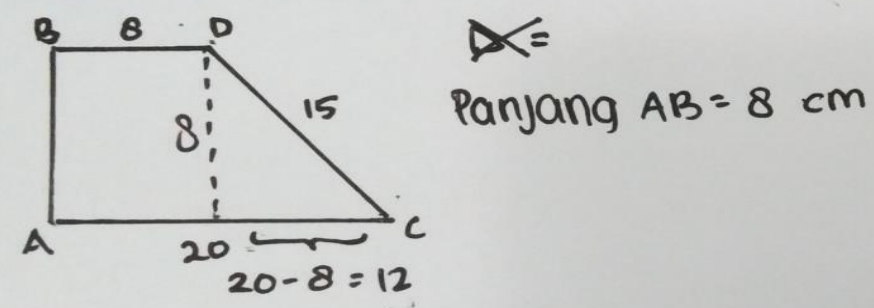

Figure 5. Student C's Answer on the Third Question

Interview result with student $C$ regarding the answer on the third question is presented below.

Researcher : Can you explain your answer? How is the process so that you answer it this way?

C : First, to make it simpler to solve the question, I drew the trapezium like in the question. Second, as the instruction told me to use the Pythagorean theorem, I thought about the right triangle, then I found where the position of the right triangle was. I got this, Sir (while pointing at the right triangle in the trapezium picture). Third, the question asked about the length of the $\mathrm{AB}$ side. This length is the same as this (while pointing at the dotted line). But this length was unknown so that I got it by $20-8=12$. Next, I applied it into

Pythagorean theorem formula.

Researcher : What is the formula of the Pythagorean theorem that you know? 
C : This is what I remember, Sir, the squared number (while pointing at the hypotenuse) and this squared number (while pointing at the opposite).

Researcher : Now you apply for the numbers in Pythagorean theorem?

C : Yes, Sir (while writing and calculating). The result is 9 , isn't it, not 8

Student C's answer sheet showed that the student was not capable of writing the procedure and algorithm in figuring out the length of the $A B$ side using the Pythagorean theorem. However, the interview with student $C$ revealed that the student had the capability of describing the procedure to solve the third question. Based on onto-semiotic approach (Godino, Batanero, \& Roa, 2005; Font, Godino, \& D' Amore, 2007), this phenomenon shows that students can describe the procedure to solve the question but find it complicated to describe mathematical ideas in the form of symbols (number, dot, line, equation).

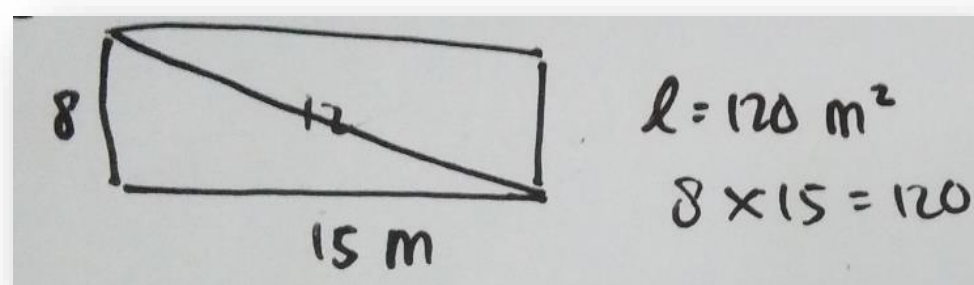

Figure 6. Student D's Answer on the Fourth Question

The result of the interview with student D related to his answer to question four is presented below.

Researcher : What is the meaning of your answer?

D : Based on the question, I draw a rectangle with an area of 120 , and one of its side lengths was 15 . What I remember is that area of the rectangle is obtained by multiplying length and width. Based on this, I write this equation (it means ... $\times 15=120$ ), and I get that its value is 8 .

Researcher : To you, are ...x 15=120 and ...=120:15 the same? 
D : Yes, Sir, they are the same. The value of ... is the same for this (while pointing at the first equation) and this (while pointing at the second equation)

Researcher : How can you get the 12 (while pointing at the diagonal line on the student's rectangle picture)?

D : I do not know this, Sir. I got the answer from my friend.

Researcher : But you know diagonal, don't you?

D : I do, Sir. It is the line that divides the rectangle into two.

Researcher : Do you know which the right triangle in this picture is?

D : This one, Sir (while pointing at the right triangle in the picture).

Researcher : How do you calculate the length of this diagonal?

D : Hmm... We can use the Pythagorean formula, can't we, Sir?

Researcher : Why did you answer only up to here (while pointing at the student's answer sheet)?

D : Honestly, Sir, I was running out of time when I was doing this. So, I did not manage to finish answering the question.

The interview result with student $\mathrm{D}$ revealed that the student was capable of defining and describing the concept of rectangle area, and principles of algebra operation as the basis in determining the length of one of the rectangle sides. The interview result also showed that participant D considered it complicated in writing the procedure, which resulted in finding out the diagonal length using the Pythagorean theorem in the form of mathematical symbols. Participant D wrote the diagonal length of 12 after he took a look at his friend's answer. Student D's difficulty in writing the correct procedure to solve the question was due to the limited time. Based on onto-semiotic approach (Godino, Batanero, \& Roa, 2005; Font, Godino, \& D' Amore, 2007), participant D could describe the procedure, algorithm, and technique in solving questions well, but he found it complicated to describe mathematical ideas in the form of symbols (number, dot, line, equation) to solve the problem. 
The ability to describe mathematical ideas in the form of symbols is widely known as symbolic representation (Villegas, Castro, \& Gutierrez 2009; Anwar \& Rahmawati, 2017). Symbolic representation ability is very beneficial in solving mathematical problems (Dundar, 2015; Li, Zhang, Chen, Deng, Zhu, \& Yan 2018). Several previous research has shown that students find difficulties in learning Pythagorean theorem due to symbolic representation ability (Arifin, 2018; Niko, Wahyuni \& Nurhayati, 2018; Misbakhudin, 2018).

\section{CONCLUSION}

Research findings signify that within the topic of understanding the Pythagorean theorem, students experienced difficulties in understanding definition, describing symbols or notations of mathematical objects, and interpreting mathematical objects in the form of procedure in solving mathematics questions. Whereas within the topic of Pythagorean theorem application, students could describe procedure, algorithm, and technique in solving questions well, but he found it complicated to describe mathematical ideas in the form of symbols (number, dot, line, equation) to solve the problem.

\section{REFERENCES}

Ahmady, G., \& Ruhi, N. N. (2016). Impact of promoting whole-class discussions in geometry instruction on students' reasoning ability. International Journal of Humanities and Cultural Studies (IJHCS) ISSN 2356-5926, 1(1), 2079-2092. Retrieved from http://www.ijhcs.com /index.php/ijhcs/ article/view/1792.

Alfian, H., Sugiatno, \& Hamdani. (2016). Mengatasi hambatan pemahaman konseptual matematis dengan pendekatan antisipasi didaktis materi dalil Pythagoras di SMP.Jurnal Pendidikan dan Pembelajaran Khatulistiwa, 6(1), 1-16. Retrieved from https://jurnal.untan.ac.id/index. php/jpdpb/article/view/18108.

Al-Khateeb, M. A. (2016). The extent of mathematics teacher's awareness of their students' misconceptions in learning geometrical concepts in the intermediate education stage. European Scientific Journal, ESJ, 12(31), 357372. https://doi.org/ 10.19044/esj.2016.v12n31p357.

Amin, M. E. I. A., Juniati, D., \& Sulaiman, R. (2018). Onto semiotic approach to analyze students' understanding of algebra based on math ability. In AIP Conference Proceedings, 2014(1), 020077. AIP Publishing. https://aip. scitation.org/doi/pdf/10.1063/1.5054481.

Anggraini, G. R., \& Ariyanto, A. (2017). Analisis kesulitan pemahaman konsep pada materi Pythagoras di kelas VIII SMP Negeri 3 Kartasura. Paper Presented at Prosiding SEMPOA (Seminar Nasional, Pameran Alat Peraga, dan

14 | Volume 8, No 1, June 2020 
Olimpiade Matematika) 3 2017. Retrieved from http://hdl.handle.net/ $11617 / 8795$.

Arifin, M. (2018). Profil implementasi elpsa framework dalam meningkatkan pemahaman konsep siswa tentang teorema Pythagoras. In ELPSA Conference II, 1(1). Retrieved from http://elpsa.org/proceeding/index. $\mathrm{php} / \mathrm{ec} 18 /$ article/view/55.

Anwar, R. B., \& Rahmawati, D. (2017). Symbolic and verbal representation process of student in solving mathematics problem based Polya's stages. International Education Studies, 10(10), 20-28. https://doi.org/ 10.5539/ies.v10n10p20.

Brodie, K. (2014). Learning about learner errors in professional learning communities. Educational Studies in Mathematics, 85(2), 221-239. Retrieved from https://link.springer.com/article/10.1007/s10649-013-9507-1.

Celik, A. O., \& Guzel, E. B. (2017). Mathematics teachers' knowledge of student thinking and its evidences in their instruction. Journal on Mathematics Education, 8(2), 199-210. http:/doi.org/10.22342/jme.8.2. 4144.199-210.

Cresswell, J. W. (2014). Penelitian kualitatif \& desain riset. Yogyakarta: Pustaka Pelajar.

Dundar, S. (2015). Mathematics teacher-candidates performance in solving problem with different representation style: The trigonometry example. Eurasia Journal of Mathematics, Science \& Technology Education, 11(6), 13791397. https://doi.org/10.12973/eurasia. 2015.1396a.

Etikan, I., Musa, S. A., \& Alkassim, R. S. (2016). Comparison of convenience sampling and purposive sampling. American Journal of Theoretical and Applied Statistics, 5(1), 1-4. https://doi.org/10.11648/j.ajtas.20160501.11.

Font, V., Godino, J. D., \& D'Amore, B. (2007). An onto-semiotic approach to representations in mathematics education. For the Learning of Mathematics, 27(2), 2-14. Retrieved from http://www.dm.unibo.it/ rsddm/it articoli/damore $/ 17 \% 20 \% 202007 \%$ 20FLM.pdf.

Godino, J. D., Batanero, C., \& Roa, R. (2005) 'An onto-semiotic analysis of combinatorial problems and the solving processes by university students,' Educational Studies in Mathematics, 60(1). https://doi.org/ 10.1007/s10649-005-5893-3.

Godino, J., Batanero, C., \& Font, V. (2007). The onto-semiotic approach to research in mathematics education. ZDM. Zentralblatt Für Didaktik Der Mathematik, 39, 127-135. https://doi.org/10.1007/s11858-006- 0004-1.

Guner, N. (2018). How to teach the pythagorean theorem: An analysis of lesson plans. Ankara University Journal of Faculty of Educational Sciences, 51(1), 119-141. https://doi.org/10.30964/auebfd.405041.

Ham, V. D. A. K., \& Heinze, A. (2018). Does the textbook matter? Longitudinal effects of textbook choice on primary school students' achievement in 
mathematics. Studies in Educational Evaluation, 59, 133-140. https://doi.org/10.1016/j.stueduc.2018.07.005.

Hutapea, M. L., Suryadi, D., \& Nurlaelah, E. (2015). Analysis of students' epistemological obstacles on the subject of pythagorean theorem. Jurnal Pengajaran MIPA, 20(1), 1-10. http://doi.org/10.18269/jpmipa. v20i1.555.

Ishartono, N., Nurcahyo, A., \& Setyono, I. D. (2019). Guided discovery: An alternative teaching method to reduce students' rote learning behavior in studying geometric transformation. Journal of Physics: Conference Series, 1265(1), 012019. IOP Publishing. Retrieved from https:// iopscience.iop.org/article/10.1088/1742-6596/1265/1/012019/meta.

Iori, M. (2017). Objects, signs, and representations in the semio-cognitive analysis of the processes involved in teaching and learning mathematics: A Duvalian perspective. Educational Studies in Mathematics, 94(3), 275-291. https://doi.org/10.1007/s10649-016-9726-3.

Li, Y., Zhang, M., Chen, Y., Deng, Z., Zhu, X., \& Yan, S. (2018). Children's nonsymbolic and symbolic numerical representations and their associations with mathematical ability. Frontiers in Psychology, 9, 1035. https:// doi.org/10.3389/fpsyg.2018.01035.

Maor, E. (2019). The Pythagorean theorem: A 4,000-year history. Princeton University Press.

Miles, M. B., Huberman, A. M., \& Saldana, J. (2018). Qualitative data analysis: A methods sourcebook, $4^{\text {th }}$ Edition. SAGE Publishing.

Misbakhudin, M. (2018). Kemampuan representasi matematis siswa dalam menyelesaikan masalah teorema pythagoras ditinjau dari perbedaan gender kelas VIII di SMP Negeri 1 Ngadiluwih tahun ajaran 2017/2018. Thesis. Retrieved from http://repo.iain-tulungagung.ac.id/8877/7/ $\mathrm{Bab} \% 20 \mathrm{IV}$.pdf.

Montiel, M., Wilhelmi, M. R., Vidakovic, D., \& Elstak, I. (2009). Using the ontosemiotic approach to identify and analyze mathematical meaning when transiting between different coordinate systems in a multivariate context. Educational Studies in Mathematics, 72(2), 139. https://doi.org/ 10.1007/s10649-009-9184-2.

Murphy, P. K., Alexander, P. A., Greene, J. A., \& Hennessey, M. N. (2004). Examining epistemic frames in conceptual change research: Implications for learning and instruction. Asia Pacific Education Review, 13(3), 475-486. https:// doi.org./10.1007/s12564-011-9199-0.

Niko, N., Wahyuni, R., \& Nurhayati, N. (2018). Analisis kemampuan multi representasi matematis ditinjau dari motivasi belajar siswa pada materi teorema Phytagoras kelas IX SMP Negeri 12 Singkawang. Journal of Educational Review and Research, 1(2), 92-99. Retrieved from https:// journal.stkipsingkawang.ac.idindex.php/JERR/article/view/1676. 
Ojose, B. (2015). Students' misconceptions in mathematics: analysis of remedies and what research says. Ohio Journal of School Mathematics, 72, 30-34. Retrieved from https://kb.osu.edu/bitstream/handle/1811/78927/ OJSM_72_Fall2015_30.pdf?sequence $=1$.

Pino-Fan, L. R., Assis, A., \& Castro, W. F. (2015). Towards a methodology for the characterization of teachers' didactic-mathematical knowledge. EURASIA Journal of Mathematics, Science and Technology Education, 11(6), 1429-1456. https:// doi.org/10.12973/eurasia.20151403a.

Pino-Fan, L. R., Godino, J. D., \& Font, V. (2018). Assessing key epistemic features of didactic-mathematical knowledge of prospective teachers: The case of the derivative. Journal of Mathematics Teacher Education, 21(1), 63-94. https://doi.org/10.1007/s10857-016-9349-8.

Qian, Y., \& Lehman, J. (2017). Students' misconceptions and other difficulties in introductory programming: A literature review. ACM Transactions on Computing Education (TOCE), 18(1), 1-24. https://doi.org/10.1145/ 3077618.

Robbia, D. F. (2013). Desain didaktis model problem solving pokok bahasan teorema pythagoras pada pembelajaran matematika untuk meningkatkan kompetensi matematis siswa. Thesis. Retrieved from http://reposi-tory.upi.edu/287.

Sarwadi, H. R. H., \& Shahrill, M. (2014). Understanding students' mathematical errors and misconceptions: The case of year 11 repeating students. Mathematics Education Trends and Research, 2014, 1-10. https://doi.org/10.5899/2014/metr-00051.

Sbaragli, S., Arrigo, G., D'Amore, B., Fandiño-Pinilla, M. I., Frapolli, A., Frigerio, D., \& Villa, O. (2011). Epistemological and didactic obstacles: The influence of teachers' beliefs on the conceptual education of students. Mediterranean Journal for Research in Mathematics Education, 10, 61-102. Retrieved from http://repository.supsi.ch/3384/1/Sbaragli $\% 20$ Arrigo $\% 20$ et $\% 20$ alpdf.

Villegas, J. L., Castro, E., \& Gutierrez, J. (2009). Representation in problem solving: a case study with optimization problem. Electronic Journal of Research in Education Psychology, 17(7), 279-308. Retrieved from http://repositorio.ual.es/bitstream/handle/10835/713/Art_17_297_en g.pdf?sequence $=1$.

Zuya, H. E. (2014). Mathematics teachers" responses to students" misconceptions in algebra, International Journal of Research in Education Methodology, 6,(2), 830-836. Council for Educative Research. Retrieved from https://dspa-ce.unijos.edu.ng/jspui/bitstream/123456789/2450 /1/3880-Article\%20Text-4405-2-10-20180104.pdf. 
Rudi1), Didi Suryadi2), Rizky Rosjanuardi3)

Zuya, E. H., \& Kwalat, S. K. (2015). Teacher's knowledge of students about geometry. International Journal of Learning, Teaching and Educational Research, 13(3), 100-114. Retrieved from http://mail.ijlter.org/index.php /ijlter/ article/view/ 438.

18| Volume 8, No 1, June 2020 